\title{
Fetal haemopoiesis marking low-grade urinary bladder cancer
}

\author{
M Wolk ${ }^{*, 1}$ and JE Martin' \\ 'Blizard Institute, Barts and The London School of Medicine and Dentistry, Queen Mary University of London, Core Pathology Facility, The Royal London \\ Hospital, 80 Newark Street, London EI 2ES, UK
}

BACKGROUND: The immunohistochemical features of fetal haemoglobin cells and their distribution patterns in solid tumours, such as colorectal cancer and blastomas, suggest that fetal haemopoiesis may take place in these tumour tissues. These locally highly concentrated fetal haemoglobin (HbF) cells may promote tumour growth by providing a more efficient oxygen supply.

METHODS AND RESULTS: Biomarkers of HbF were checked in transitional cell carcinoma (TCC) of the urinary bladder, assessing this as a new parameter for disease management. Fetal haemoglobin was immunohistochemically examined in tumours from 60 patients with TCC of the bladder. Fetal haemoglobin erythrocytes and erythroblasts were mainly clonally distributed in proliferating blood vessels and not mixed with normal haemoglobin erythrocytes. The proportion of such HbF blood vessels could reach more than half of the total number of vessels. There were often many HbF erythroblasts distributed in one-cell or two-cell capillaries and present as 5- $15 \%$ of cells in multi-cell vessels. This suggests a local proliferation of HbF-cell progenitors. Fetal haemoglobin cells were prominently marking lower grades of tumours, as $76 \%(n=2 \mathrm{I})$ of the patients with GlpTa were HbF+, whereas only $6.7 \%(n=30)$ of the patients with G3pTI-pT2a were HbF+.

CONCLUSION: Our results suggest that HbF, besides being a potential new marker for early tumour detection, might be an essential factor of early tumour development, as in fetal life. Inhibiting HbF upregulation may provide a therapeutic target for the inhibition of tumour growth.

British Journal of Cancer (2012) 107, 477-48I. doi:I0.1038/bjc.2012.268 www.bjcancer.com

Published online 26 June 2012

(C) 2012 Cancer Research UK

Keywords: HbF; fetal haemoglobin; bladder cancer; fetal haemopoiesis

Systemic, high, whole blood concentration of fetal haemoglobin $(\mathrm{HbF})$ is a well-established feature of haematological and solid tumours (Sheridan et al, 1976; Wolk et al, 1988, 1991, Rautonen and Mari, 1990). However, there is evidence suggesting local proliferation of HbF cells in tumour tissues. This was serologically demonstrated in lymphoma, ovarian cancer, brain cancer and other cancers by a high plasma HbF concentration independent of the whole blood concentration (Wolk et al, 1999). The same was also immunohistochemically shown in colorectal tumours (Wolk et al, 2006), as well as in blastomas (Wolk et al, 2007), by high concentrations of $\mathrm{HbF}$ erythroid cells, distributed as separated clusters rather than mixed with the normal erythrocytes, in blood vessels. To investigate this trait further, we decided to examine $\mathrm{HbF}$ in transitional cell carcinoma (TCC) of the urinary bladder in relation to the grade and stage of the disease. Although new markers for TCC have been evaluated during the past decade in order to improve management, they have not replaced traditional methods of urine cytology, although this is limited by its low sensitivity (Mukhtar and Perry, 2011). The most promising of these new techniques involve specific protein immunoassay (Stoeber et al, 2002) or molecular (Miyake et al, 2010) and genomic (Wang et al, 2009) biomarkers and require complicated techniques, which are not yet compatible with clinical practice. Fetal haemoglobin, however, if proved a suitable marker for TCC, might be easily evaluated serologically in blood or urine and by immunohistochemistry in tumour biopsies.

*Correspondence: Dr M Wolk; E-mail: wolkl@bezeqint.net Received 7 March 2012; revised 16 May 2012; accepted 20 May 2012; published online 26 June 2012

\section{MATERIALS AND METHODS}

\section{Participants}

The study was conducted in the Blizard Institute, Core Pathology Group, Barts and The London School of Medicine and Dentistry, using archival and stored materials. The study was approved by the Research Ethics Committee of the East London and City Health Authority. Histopathological specimens from bladder TCC patients were selected from the archive of the Department of Histopathology, the Royal London Hospital. The grade and stage of tumours were derived from records and reviewed for the blocks studied. The study comprised 60 patients, of whom 9 were women. The patients' age range was 43-97 years (median $=76$ ); the grade distribution was as follows: 21 patients $=\mathrm{G} 1,8=\mathrm{G} 2,30=\mathrm{G} 3$ and $1=$ in situ TCC. Five controls of non-malignant bladder tissues were examined in parallel. No chemotherapy treatment was given at least 6 months preceding excision of the specimens.

\section{Immunohistochemical staining}

We used the peroxidase-labelled avidin-biotin method (Hsu and Raine, 1984). Formalin-fixed, paraffin wax-embedded crosssections were cut at $3 \mu \mathrm{m}$, dewaxed, and then blocked for endogeneous peroxidase with $3 \% \mathrm{H}_{2} \mathrm{O}_{2}$ in water for $15 \mathrm{~min}$, and washed for $5 \mathrm{~min}$ in water and then for $5 \mathrm{~min}$ in TBS $(0.05$ tris buffered saline) wash buffer (Dako A/S, Glostrup, Denmark). The following incubation steps were used: (1) blocking with normal rabbit serum, diluted 1:5 for $30 \mathrm{~min}$; (2) incubation with primary antibody, that is, affinity-purified sheep anti-human $\mathrm{HbF}$ (Abcam, Cambridge, UK), diluted 1:400 for $60 \mathrm{~min}$; (3) incubation 
with secondary antibody, i.e., biotinylated rabbit anti-sheep IgG (Vector Laboratories, Burlingame, CA, USA), diluted 1:150 for $30 \mathrm{~min}$; (4) incubation with ready-to-use streptavidin-biotin complex (RTU Vectastain Elite ABC, Vector Laboratories) for 30 min; and (5) incubation with $\mathrm{DAB}$ solution (chromogen; DAB kit, Vector Laboratories) for $4 \mathrm{~min}$. The sections were then washed for $5 \mathrm{~min}$ in running water, automatically counterstained with Gill's haematoxylin, blue-differentiated, dehydrated and mounted. Between steps (1) through (4), the sections were washed in TBS wash buffer for $5 \mathrm{~min}$. Staining was confirmed by two controls, where in step (2) we used the same anti-human HbF absorbed with $\mathrm{HbF}$ as negative control and human $\mathrm{HbF}$ absorbed with normal haemoglobin $(\mathrm{HbA})$ as positive control. Fetal haemoglobin and $\mathrm{HbA}$ were prepared from the corresponding red cell lysates, insolubilised by the aid of gluteraldehyde (Wolk and Kieselstein, 1983) and then two volumes of anti-HbF were shaken at room temperature for $12 \mathrm{~h}$, with one volume of either of those absorbents. The supernatants were then saved for control staining in place of the primary antibody.

\section{RESULTS}

The criteria for positivity were as follows: (1) proliferating fine vessels with $100 \% \mathrm{HbF}$ blood cells, distributed throughout the section; and (2) larger blood vessels with $>50 \% \mathrm{HbF}$ blood cells. Negative cases were sections without $\mathrm{HbF}$ blood cells, or with occasional $<1 \%-5 \% \mathrm{HbF}$ blood cells. As shown in Table 1 , the percentage of $\mathrm{HbF}+$ tumours was much higher in the noninvasive, low-grade G1 group (76\%) than in the high-grade G3 group $(6.7 \%)$, whereas in the G2 group it was intermediate $(50 \%)$.

Fetal haemoglobin blood cell distribution is given in Table 2, in which a distinction is made between three kinds of blood vessels: (1) with adult haemoglobin (HbA) blood cells, (2) with a mixed population, including $10-40 \% \mathrm{HbF}$ cells and (3) with predominantly $\mathrm{HbF}$ blood cells, $>50 \% \mathrm{HbF}$ cells. As shown in this table, the percentages of $\mathrm{HbF}+$ vessels were, in most cases, over $50 \%$ (Figures 1A-C). Proliferation of $\mathrm{HbF}$ cells was indicated by nucleated (erythroblast and proerythroblast) cells filling one- or two-cell capillaries (Figure 2) or mixed with the $\mathrm{HbF}$ erythrocytes (Figures 1, 3 and 4). As shown in Table 2, the HbF blood vessels were distributed within the tumour (Figures 3 and 4) and in the lamina propria (Figures $1 \mathrm{~A}-\mathrm{C}$ ), where the most intensive proliferation of fine blood vessels was noted. The $\mathrm{HbF}$ and the non-HbF blood vessels were distributed in separated areas throughout the sections. Proliferation of blood vessels with nonHbF blood cells, although present in low-grade G1 patients, was most prominent between the invasive tumour cells of high-grade G3 patients (Figure 5), where no vessels with $\mathrm{HbF}$ cells were observed.

Five control biopsies from patients suspected of cancer, which were normal, were all without $\mathrm{HbF}$ blood cells.

Table I Ratios of positive $\mathrm{HbF}(\mathrm{HbF}+)$ and negative $\mathrm{HbF}(\mathrm{HbF}-)$ patients in different grades of TCC (\%)

\begin{tabular}{|c|c|c|c|c|}
\hline \multirow[b]{2}{*}{ Grade } & \multicolumn{2}{|c|}{$\mathbf{H b F}+$} & \multicolumn{2}{|c|}{ HbF - } \\
\hline & $\begin{array}{l}\text { Total no. of } \\
\text { patients }\end{array}$ & $\begin{array}{c}\text { Stage } \\
\text { distribution }\end{array}$ & $\begin{array}{l}\text { Total no. of } \\
\text { patients }\end{array}$ & $\begin{array}{c}\text { Stage } \\
\text { distribution }\end{array}$ \\
\hline & & pTa I la 2 2a & & pTa I la 2 2a \\
\hline Gl & $16(76)$ & 16 & $5(24)$ & 5 \\
\hline $\mathrm{G} 2$ & $4(50)$ & 22 & $4(50)$ & 4 \\
\hline G3 & $2(6.7)$ & I & $28(93.3)$ & $\begin{array}{llll}14 & 1 & 1 & 12\end{array}$ \\
\hline
\end{tabular}

Abbreviation: TCC $=$ transitional cell carcinoma.

\section{DISCUSSION}

Local proliferation of $\mathrm{HbF}$ blood cell progenitors within the tumour is likely to be the main mechanism responsible for the high concentration of $\mathrm{HbF}$ blood cells. The histological picture shows multiple nucleated HbF cells (Figure 1, Table 2), sometimes filling up small capillaries (Figure 2), and proliferative patterns of fine to
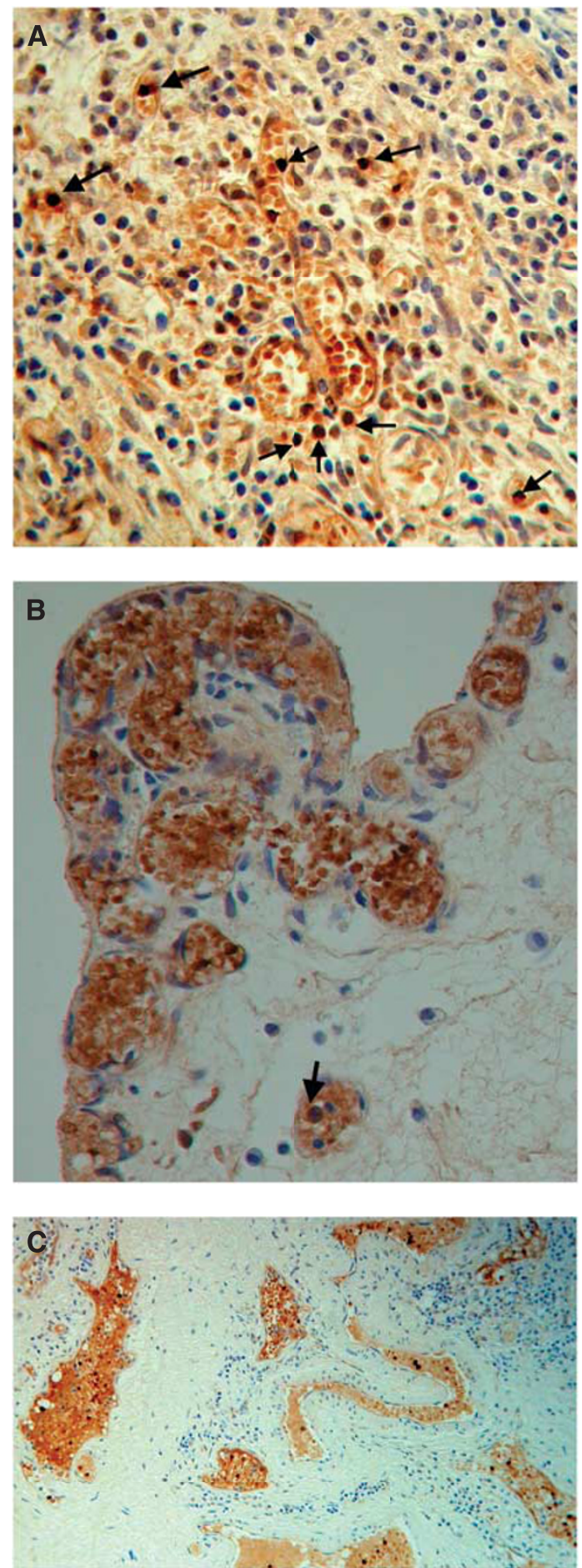

Figure I Stages in proliferation of blood vessels with $\mathrm{HbF}$ cells in lamina propria of GI TCC. Arrows indicating nucleated HbF progenitor cells: (A) clusters of $\mathrm{HbF}$ cells forming into fine vessels with many foci of nucleated $\mathrm{HbF}$ progenitor cells. (B) High density of small proliferating blood vessels. (C) Larger blood vessels spreading throughout the lamina propria. 


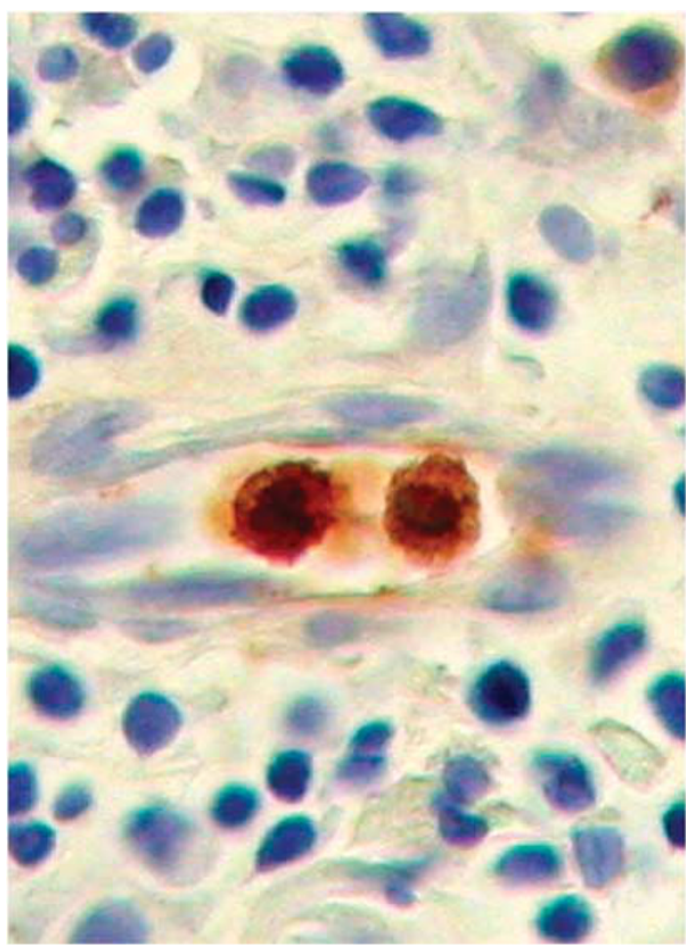

Figure 2 Small capillary with two HbF erythroblasts.

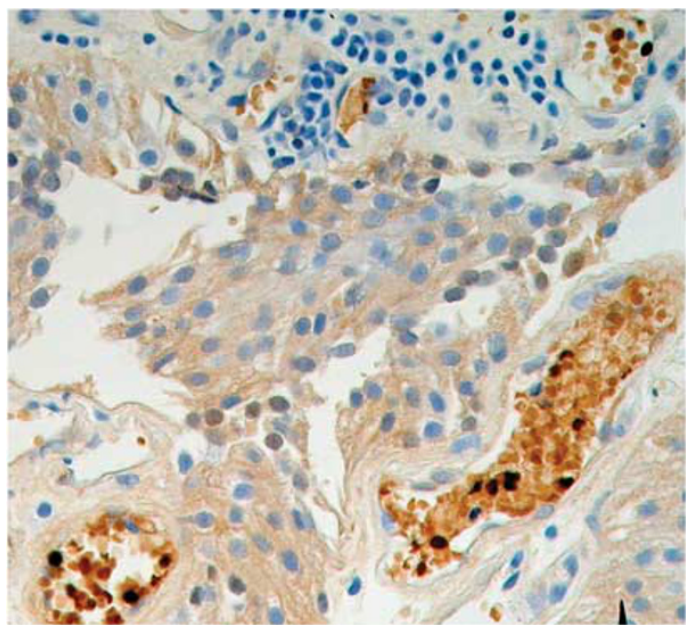

Figure 3 Fetal haemoglobin cells, including nucleated (dark) cells, within tumour cells of GI TCC.

bigger blood vessels, filled predominantly with $\mathrm{HbF}$ cells apart from the normal $\mathrm{Hb}$ vasculature, probably due to the local fetal haemopoiesis in the tumour tissue. The extremely high concentration of blood vessels with $\mathrm{HbF}$ cells throughout TCC bladder tissue makes the bladder erythroid blood supply predominantly a fetal one. Owing to its high oxygen affinity, HbF might have a particular role in supporting cancer growth by providing an efficient oxygen delivery to the cells, as it does in fetal tissues during gestation (Carlson, 1988; Manca and Masala, 2008). Fetal haemoglobin ( $\mathrm{HbF}$ ) gene upregulation might thus be an important factor in supporting low-grade tumours, and it is possible that its inhibition may help to arrest the malignant process at an early stage. This is relevant to therapeutic strategies for tumours, aimed at angiogenesis, which is an important strategy in cancer therapy (Wu et al, 2008; Goel et al, 2011). We therefore suggest that the reduction of $\mathrm{HbF}$ cells inside

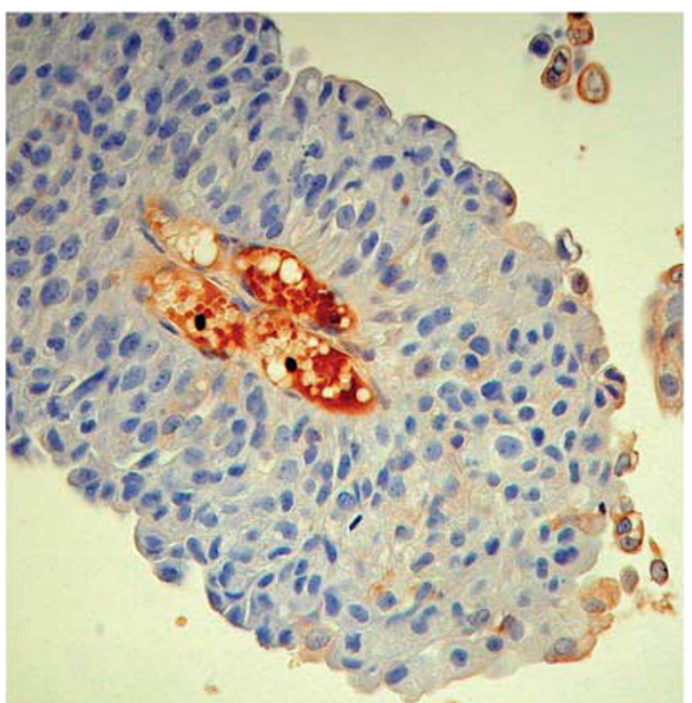

Figure 4 Fetal haemoglobin cells including nucleated (dark) cells, within tumour cells of G2 TCC.

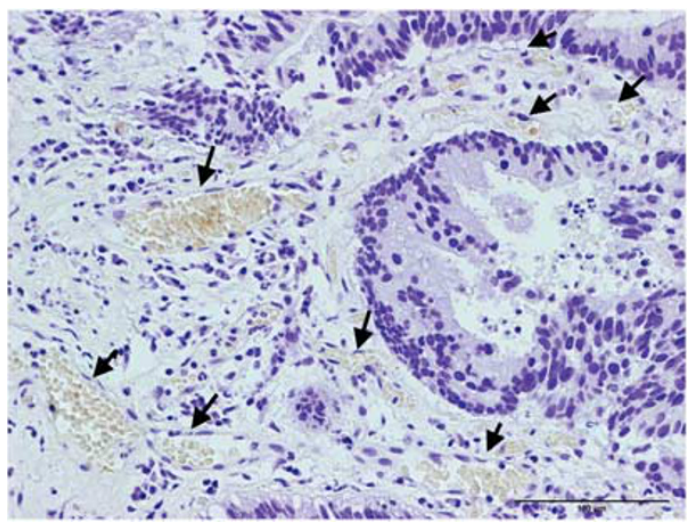

Figure 5 G3 TCC tumor with proliferating blood vessels (arrows) filled with normal $\mathrm{Hb}$ blood cells.

tumour vasculature, along with inhibiting proliferation of the unique endothelial cells of the tumour, might be a useful approach.

Despite many studies having been conducted, the molecular mechanism of $\mathrm{HbF}$ regulation is not completely understood. However, in the silencing of $\gamma$-genes expression in normal adults, there is thought to be a fundamental role of DNA methylation (Lavelle, 2004; Saunthararajah et al, 2004; Sankaran, 2011). Consequent to methylation, there is induction of histone deacetylation of the chromatin, causing a closed chromatin configuration around the methylated sequences, which maintain silencing of those genes (Lavelle, 2004). Methods for restoring histone deacetylation might be useful in downregulation of $\mathrm{HbF}$ and reduction of $\mathrm{HbF}$ cell concentration in tumour tissues to normal levels. These might include reactivation of the enzymes DNA methyl transferase (DNMT) and histone de-acetylase (HDAC) in those erythroid cells progenitors, as inhibitors of these enzymes are used to upregulate $\mathrm{HbF}$, therapeutically (Saunthararajah et al, 2004) for DNMT or experimentally (Witt et al, 2003) for HDAC. Reactivation of HbF has been shown to be mediated by certain signalling mechanisms that activate $\gamma$-globin genes via upregulation of transcription factors. These signalling mechanisms include activation of receptor tyrosine kinase CD117 (c-kit) on the surface of erythroid progenitor cells by stem cell factor (c-kit ligand), which has a key role in $\mathrm{HbF}$ reactivation in 
Table 2 Distribution of blood vessels containing different proportion of HbF blood cells, in $\mathrm{HbF}+$ TCC patients (\%)

\begin{tabular}{|c|c|c|c|c|c|c|c|c|}
\hline $\begin{array}{l}\text { Patient } \\
\text { no. }\end{array}$ & $\begin{array}{c}\text { Number of } \\
\text { vessels with } \\
\text { non-HbF } \\
\text { cells }\end{array}$ & $\begin{array}{c}\text { Number of } \\
\text { vessels with } \\
\text { mixed (HbF }+ \\
\text { and } \\
\mathrm{HbF}^{-} \text {) cells }\end{array}$ & $\begin{array}{c}\text { Number of } \\
\text { vessels } \\
\text { with } \\
\text { HbF + cells }\end{array}$ & $\begin{array}{c}\text { Proliferation } \\
\text { of HbF cell } \\
\text { vessels }\end{array}$ & $\begin{array}{l}\text { HbF cell } \\
\text { vessels } \\
\text { between } \\
\text { tumour } \\
\text { cells }\end{array}$ & $\begin{array}{l}\text { HbF cell } \\
\text { vessels } \\
\text { in } \\
\text { lamina } \\
\text { propria }\end{array}$ & $\begin{array}{l}\text { Nucleated } \\
\text { HbF cells }\end{array}$ & $\begin{array}{l}\text { Pathological } \\
\text { grade/stage }\end{array}$ \\
\hline 1 & $104(19)$ & $150(28)$ & $288(53)$ & + & + & + & $+(15)$ & GIpTa, no invasion \\
\hline 2 & $22(18)$ & $3(2.4)$ & $98(78.6)$ & + & + & + & $+(5-10)$ & GlpTa, no invasion \\
\hline 3 & $19(12)$ & $47(29)$ & $95(59)$ & + & + & + & $+(<5)$ & GlpTa, no invasion \\
\hline 6 & $66(39)$ & $56(33)$ & $46(31)$ & - & - & + & ND & GlpTa, no invasion \\
\hline 7 & $5(12)$ & $8(19)$ & $30(69)$ & + & - & + & $+(>15)$ & GlpTa, no invasion \\
\hline 8 & $27(47)$ & ND & $30(53)$ & - & + & - & ND & GlpTa, no invasion \\
\hline 9 & I (3) & ND & $29(97)$ & - & - & + & ND & GlpTa, no invasion \\
\hline 10 & $6(18)$ & ND & $28(72)$ & + & + & - & $+(14)$ & GlpTa, no invasion \\
\hline II & $21(51)$ & ND & $20(49)$ & - & - & + & $+(10-20)$ & GlpTa, no invasion \\
\hline 12 & ND & ND & $19(100)$ & + & + & - & $+(7)$ & GlpTa, no invasion \\
\hline 18 & $60(33)$ & $42(23)$ & $80(44)$ & + & + & + & $+(5)$ & G2pTI, inv lamina propria \\
\hline 19 & ND & ND & $20(100)$ & - & + & - & ND & G2pTa, no invasion \\
\hline 20 & $70(42)$ & $32(19)$ & $65(39)$ & + & + & - & $+(10)$ & G2pTI, inv lamina propia \\
\hline 21 & $6(60)$ & ND & $4(40)$ & - & - & + & ND & G3pTI, inv lamina propria \\
\hline 22 & $4(33)$ & ND & $8(67)$ & - & - & + & ND & G3pT2a, inv lamina propria \\
\hline
\end{tabular}

Abbreviations: $\mathrm{HbF}=$ fetal haemoglobin; $\mathrm{ND}=$ not detected; $\mathrm{TCC}=$ transitional cell carcinoma.

adult life (Wojda et al, 2003; Bhnu et al, 2004; Gabbianelli et al, 2010). Inhibitors of that signalling pathway, such as PD98059 (Bhnu et al, 2004), might be used to reduce the concentration of erythroid $\mathrm{HbF}$ cells where they may support cancer growth. Another approach to downregulation of $\mathrm{HbF}$ was shown in leukaemia cell lines, in which the concentration of $\mathrm{HbF}$ decreased to $15-5 \%$ of the control upon inhibition of the P-glycoprotein drug efflux pump (P-gp) (Fyrberg et al, 2011), indicating a link between $\mathrm{P}$-gp and the induction of $\mathrm{HbF}$.

The high incidence of blood vessels with predominant $\mathrm{HbF}$ erythroid cells in non-invasive low-grade tumours of the bladder suggests $\mathrm{HbF}$ as a potential prognostic marker in early stages of the disease. The use of $\mathrm{HbF}$ as such a marker requires larger-scale observation in TCC, as well as in other solid tumours. Evaluation of bladder $\mathrm{HbF}$ could be facilitated by measuring its concentration in plasma or urine, in order to avoid invasive procedures. We have previously shown that $\mathrm{HbF}$ is a potential systemic blood marker

\section{REFERENCES}

Bhnu NV, Trice TA, Lee YT, Miller JL (2004) A signaling mechanism for growth-related expression of fetal hemoglobin. Blood 103: 1929-1933

Carlson BM (1988) The development of the circulatory system. In Patten's Foundations of Embryology, Dolinger E, Maisel J (eds). pp 594. McGraw-Hill: New York

Fyrberg A, Peterson C, Kagedal B, Lotfi K (2011) Induction of fetal hemoglobin and $\mathrm{ABCB} 1$ gene exspression in 9- $\beta$-D-arabinofuranosylguanineresistant MOLT-4 cells. Cancer Chemother Pharmacol 68: 583-591

Gabbianelli M, Testa U, Morsilli O, Pelosi E, Saulle E, Petrucci E, Casteli G, Giovinazzi S, Mariani G, Fiori ME, Bonanno G, Massa A, Corce CM Fontana L, Peschele C (2010) Mechanism of human Hb switching: a possible role of the kit receptor/miR 221-222 complex. Haematologica 95: 1253-1260

Goel S, Duda DG, Xu L, Munn LL, Boucher Y, Fukumura D, Jain RK (2011) Normalization of the vasculature for treatment of cancer and other diseases. Physiol Rev 9: 1071-1121

Hsu Sb, Raine L (1984) The use of avidin-biotin-peroxidase complex (ABC) in diagnostic and research pathology. In Advances in Immunochemistry, Delellis Ra (ed). pp 31-42. Mason: New York in these patients, as all 10 patients who were serologically examined had elevated concentrations of $\mathrm{HbF}$ in the blood (Wolk et al, 1988, 1991). It will be important to scrutinise the incidence and biological behaviour of a range of tumours, including bladder tumours, in light of the increasing use of drugs to induce $\mathrm{HbF}$ therapeutically.

\section{ACKNOWLEDGEMENTS}

We acknowledge the technical assistance of C Evagora, P levey, $\mathrm{R}$ Carrol and M Child from Queen Mary University of London ICMS/Pathology Group, The Royal London Hospital.

\section{Conflict of interest}

The authors declare no conflict of interest.
Lavelle DE (2004) The molecular mechanism of fetal hemoglobin reactivation. Semin Hematol 41(4, suppl 6): 3-10

Manca L, Masala B (2008) Disorder of synthesis of human fetal hemoglobin. IUBMB Life 60: 94-111

Mukhtar S, Perry M JA (2011) Future prospects for bladder cancer biomarkers. Brit J Urol Int 108: 1336-1345

Miyake M, Sugano K, Sugino $\mathrm{H}$, Imai $\mathrm{K}$, Mutsumoto $\mathrm{E}$, Maeda $\mathrm{K}$, Fukozono S, Ichikawa H, Kawashima K, Hirabayashi K, KJodama T, Fujimoto H, Kakizoe T, Kanai Y, Fujimoto K, Hirao Y (2010) Fibroblast growth factor receptor 3 mutation in voided urine is a useful diagnostic marker and significant indicator of tumor recurrence in non-muscle invasive bladder cancer. Cancer Sci 101: 250-258

Rautonen J, Mari AS (1990) Initial blood fetal hemoglobin concentration is elevated and is associated with prognosis in children with acute lymphoid or myeloid leukemia. Blut 61: 17-20

Sankaran VG (2011) Targeted therapeutic strategies for fetal hemoglobin induction. Heamatol Am Soc Heamatol Educ Program 2011: 459-465 
Saunthararajah Y, Lavelle D, DeSimone J (2004) DNA hypo-methylation agents and sickle cell disease. Brit J Haematol 126: 629-636

Sheridan BL, Weatherhall DJ, Clegg JB, Prichard J, Wood WG, Challender ST, DUrrant IJ, McWhirter WR, Ali M, Partridge JW, Thompson EN (1976) The patterns of fetal haemoglobin production in leukaemia. Brit J Haematol 32: 487-506

Stoeber K, Swinn R, Prevost AT, de Clive-Lowe P, Halsall I, Dilworth SM, Marr J, Turner WH, Bullock N, Doble A, Hales CN, Williams GH (2002) Diagnosis of genito-urinary tract cancer by detection of minichromosome maintenance 5 protein in urine sediments. J Natl Cancer Inst 94: 1071-1079

Wang R, Morris DS, Tonlis SA, Lonigro RJ, Tsodikov A, Mehra R, Giorando TJ, Kunjo LP, Lee CT, Weizer AZ, Chinaian AM (2009) Development of a multiplex quantitative PCR signature to predict progression in nonmuscle-invasive bladder cancer. Cancer Res 69: 3810-3818

Witt O, Monkemeyer S, Roenndahl G, Erdlenbruch B, Reinhardt D, Kanbach K, Pekrun A (2003) Induction of fetal hemogloboin expression by the histone deacetylase inhibitor ampicin. Blood 101: 2001-2007

Wojda U, Leigh KR, Njoroge JM, Jackson KA, Natarajan B, Stitely M, Miller JL (2003) Fetal hemoglobin modulation during human erythropoiesis: stem cell factor has "late" effects related to the expression pattern of CD117. Blood 101: 492-497

Wolk M, Kieselstein M (1983) Graded hemagglutination inhibition for quantification of human fetal hemoglobin. Clin Chem 29: 1372-1375

Wolk M, Kiesekstein M, Brufman G (1988) Evaluation of fetal hemoglobin in various malignancies with reference to the patients' age. Tumor Biol 9: 95-100

Wolk M, Kieselstein M, Ben-Dor CG, Brufman G (1991) Fetal Hemoglobin screening in whole blood and in plasma of cancer patients. Tumor Biol 12: $45-51$

Wolk M, Newland AC, Dela Salle B, Peleg M, Brufman G (1999) Refinement of plasma fetal hemoglobin (HbF) measurements, as related to whole blood HbF, in cancer patients. J Tumor Marker Oncol 14: 115-124

Wolk M, Martin JE, Reinus C (2006) Development of fetal haemoglobin-blood cells (F cells) within colorectal tumour tissues. J Clin Pathol 59: 598-602

Wolk M, Martin JE, Nowicki M (2007) Foetal haemoglobin-blood cells (F-cells) as a feature of embryonic tumours (blastemas). Brit J Cancer 97: 412-419

Wu H-C, Huang C-T, Chang D-K (2008) Anti-angiogenic therapeutic drugs for treatment of human cancer. J Cancer Mol 4: 37-45

This work is published under the standard license to publish agreement. After 12 months the work will become freely available and the license terms will switch to a Creative Commons Attribution-NonCommercial-Share Alike 3.0 Unported License. 